\title{
PEMBERDAYAAN MASYARAKAT MISKIN, MELALUI PROSES PENDIDIKAN NONFORMAL, UPAYA MENINGKATKAN KESEJAHTERAAN SOSIAL DI KABUPATEN HALMAHERA BARAT
}

\section{THE EMPOWERMENT OF THE POOR THROUGH THE NON-FORMAL EDUCATION PROCESS AS AN EFFORT TO IMROVE THE SOCIAL WELFARE IN WEST HALMAHERA REGENCY}

\author{
Safri Miradj, Sumarno \\ Universitas Muhammadiyah Maluku Utara, Universitas Negeri Yogyakarta \\ safri_miraj@yahoo.co.id, sumarno_unj@yahoo.co.uk
}

\begin{abstract}
Abstrak
Tujuan penelitian untuk mengetahui proses pemberdayaan melalui pendidikan nonformal dalam melaksanakan kegiatanpelatihankepada masyarakat miskin untuk meningkatkan kesejahteraan sosial di Kabupaten Halmahera Barat. Penelitian kualitatif, pendekatan fenomenologi, sampel penelitian, PKBM Mario Laha, PKBM Merpati, Orsos Melati, Orsos Tunas Harapan dan Lembaga Pemberdayaan Masyarakat (LPM) Sonyinga, responden, penggelola lembaga, masyarakat miskin atau warga belajar, dan tokoh masyarakat. Pengumpulan data, metode observasi, wawancara, dan dokumentasi. Hasil penelitian yaitu, (1) proses pemberdayaan yang dilakukan lembaga pendidikan nonformal belum sesuai harapan warga belajar yang terlibat dalam proses tersebut, dan belum memperhatikan aspek kebutuhan yang diperlukan warga belajarnya, (2) hasil yang di timbulkan pasca mengikuti proses pemberdayaan di lembaga-lembaga pendidikan nonformal belum membantu masyarakat miskin meningkatkan kehidupannya, dan (3) hubungan kerja sama yang selama ini dibangun oleh PKBM Merpati, PKBM Mario Laha, Orsos Tunas Harapan, Orsos Melati, dan LPM Sonyinga hanya sebatas pemerintah daerah.
\end{abstract}

Kata kunci: pemberdayaan, kemiskinan, pendidikan nonformal, kesejahteraan sosial, PKBM, Orsos, dan LPM.

\begin{abstract}
This study aims to investigate the empowerment process through non-formal educational institutions in the implementation of training activities for the poor to improve the social welfare in West Halmahera Regency. This study employed the qualitative using the phenomenological approach. The sample comprised MarioLaha Center for Community Learning Activities (CCLA), Merpati CCLA, Melati Social Organization (SO), Tunas Harapan SO, and Sonyinga Community Empowerment Institution (CEI). The respondents included the managerial personnel of the institutions, the poor people or learning participants, and community leaders. The data were collected through observations, interviews, anddocumentation. The findings show that: (1) the empowerment processes carried out by non-formal educational institutions have not satisfied the expectations of the learning participants involved in the process and have not fully taken account of the aspects related to their needs, (2) the results of the empowerment processes in the nonformal educational institutions do not help the poor improve their life, and (3) the cooperative relationship that so far has been established by Merpati CCLA, Mario Laha CCLA, Melati SO, Tunas Harapan SO, and Sonyinga CEI is limited to the local government.
\end{abstract}

Keywords: empowerment, poverty, nonformal education, social welfare, CCLA, SO, CEI 


\section{PENDAHULUAN}

Kemiskinan adalah permasalahan mendasar yang terjadi pada seseorang, maka harus diselesaikan. Penanggulangan kemiskinan harus dilakukan secara sinergis dan sistematis agar seluruh masyarakat dapat menikmati kehidupan yang bermartabat. Persoalan kemiskinan bukan hanya berdimensi pada aspek ekonomi semata, tetapi juga pada dimensi sosial, budaya, politik, pendidikan, bahkan juga sampai pada tingkat ideologi. Secara umum kondisi kemiskinan tersebut ditandai oleh kerentanan, ketidakberdayaan, keterisolasian, dan ketidakmampuan untuk menyampaikan kebutuhan dan aspirasinya.

Persoalan kemiskinan juga diakibatkan dari kurang kesadaran pemerintah dan masyarakat dalam memaknai pentingnya pendidikan, sesunguhnya pendidikan itu merupakan pusat dalam pembangunan manusia yang cerdas dan berkualitas, dan sangat mendorong pertumbuhan ekonomi, politik, sosial, dan budaya demi kemajuan daerah tersebut. Dalam teori maupun konsep pembangunan, bahwa suatu daerah itu dapat dikatakan maju apabila pendidikan itu maju dan memiliki sumber daya manusia (SDM) yang berkualitas dan memiliki daya saing tinggi dengan daerah yang lain, salah satu adalah dengan jalur pendidikan.

Selama ini masih banyak program penanggulangan kemiskinan yang dilaksanakan oleh pemerintah pusat maupun pemerintah daerah seperti, pemberian bantuan, beras raskin, asuransi kesehatan keluarga miskin (Askeskin), dan bantuan langsung tunai (BLT) ataupun dengan nama lain yang saat ini menjadi trend adalah bantuan langsung tunai (BLSM). Hal ini belum mampu membantu masyarakat dari persoalan kemiskinan.

Kemiskinan bukan isu yang baru, melainkan merupakan isu yang seolah-olah abadi sepanjang jaman. Saat ini Indonesia belum bisa mengatasi kemiskinan dengan baik. Perkembangan jaman yang begitu cepat mengakibatkan sebagian masyarakat tidak menikmati pembangunan dengan hasil yang memuaskan, ini terbukti dengan data yang dirilis oleh badan statistik pusat, pada bulan Maret 2012, jumlah penduduk miskin Indonesia mencapai 29,13 juta orang. Angka ini sangat memrihatinkan dengan kondisi bangsa Indonesi yang memiliki sumber daya alam (SDA) yang begitu berlimpah yang tersebar di seluruh penjuru republik Indonesia.

Ada beberapa hal yang menyebabkan kondisi kemiskinan masih sulit untuk diminimalkan. Pertama, kondisi anggota masyarakat yang belum ikut serta dalam proses yang berkualitas, faktor produksi yang memadai, kedua rendahnya tingkat pendidikan masyarakat pedesaan, dan ketiga pembangunan yang direncanakan pemerintah tidak sesuai dengan kemampuan masyarakat untuk berpartisipasi, sehingga tidak dijangkau oleh masyarakat, (Sumarto, 2010, p.21). Oleh karena itu harus dilakukan upaya-upaya terobosan baru oleh pemerintah maupun pihak terkait untuk secepatnya membantu masyarakat membangkitkan kesadaran dan potensi yang dimilikinya agar dapat bermanfaat bagi pembangunan bangsa.

Inti dari tujuan pembangunan adalah mewujudkan suatu masyarakat yang makmur dan sejahtera baik secara individual maupun secara sosial. Hal ini dimaksudkan agar makin tumbuh kesadaran masyarakat, pentingnya pendidikan agar dapat mendorong masyarakat untuk terus berpartisipasi aktif di dalam merespon pembangunan yang berkelanjutan. Hal Ini disebabkan pada faktor yang lebih dominan yang mempengaruhi persoalan dari segi kemanusiaan dan pembangunan, seperti keterbelakangan, kebodohan, ketelantaran, kematian dini, buta huruf, anak putus sekolah, anak jalanan, pekerja anak, perdagangan manusia (human trafficking) dan penganguran, ini yang membuat sebagian masyarakat kita tidak dapat menikmati kehidupannya dengan sejahtera. Artinya, bahwa daya beli merupakan sesuatu faktor yang sangat penting untuk ditingkatkan guna memenuhi kebutuhan hidup manusia yang sejahtera dalam kehidupan saat ini. Kecukupan kebutuhan itulah yang sementara ini menjadi ukuran tentang well being atau sejahtera yang menjadi ukuran dari seseorang yang tidak termasuk dalam kategori 
orang miskin. Subtansi kemiskinan adalah kondisi depresi terhadap sumber-sumber pemenuhan kebutuhan dasar yang berupa sandang, pangan, papan, dan pendidikan.

Pernyataan ini senada dengan definisi kemiskinan yang di jelaskan oleh, Ninik Sudarwati, kemiskinan memiliki wujud yang majemuk, termasuk rendahnya tingkatan pendapatan dan sumberdaya produktif yang menjamin kehidupan, keterbatasan dan kurangnya akses kepada pendidikan dan layanan-layanan pokok lainnya; kondisi tak wajar dan kematian akibat penyakit yang terus meningkat, kehidupan bergelandangan dan tempat tinggal yang tidak memadai, lingkungan yang tidak aman, serta diskriminasi dan keterasingan, (Sudarwati, 2009, p.27).

Kabupaten Halmahera Barat, apabila dilihat secara umum dari segi Sumber Daya Manusia (SDM) masih sangat jauh dari harapan. Hal ini dipengaruhi oleh kualitas pendidikan masyarakatnya masih rendah, dibuktikan dengan penelitian yang dilakukan oleh PUSPENDIK tahun 2011 tentang evaluasi ujian nasional di seluruh kabupaten kota di Indonesia yang tingkat kelulusannya masih sangat rendah. Dibandingkan dengan kabupaten kota lain yang ada di Provinsi Maluku Utara, Kabupaten Halmahera Barat masuk dalam kategori kabupaten yang pelaksanaan ujian nasionalnya terendah.

Bagi bangsa Indonesia, untuk menjawab masalah ini tentu tidak sesederhana yang kita bayangkan. Jika kita menoleh ke belakang, dan merasakan pergolakan dan percaturan kehidupan bangsa Indonesia yang saat ini yang berada dalam tahapan negara berkembang, maka jawabannya adalah mempersiapkan SDM adalah merupakan kunci utama dalam memenangkan persaingan era globalisasi. Untuk membantu dan membebaskan masyarakat dari kemiskinan, kebodohan dan keterbelakangan, yang mengakibatkan pada rendahnya kualitas SDM, maka pendidikan adalah kunci untuk menyelesaikan persoalan tersebut. Sehingga upaya dan kerja keras untuk menuju bangsa Indonesia yang mandiri dan berdaya saing tinggi tidak bisa dilepaskan pada aspek pendidikan Nasional sebagai wadah yang bertanggung jawab dalam megembangkan SDM. Maka sasaran penggerak terletak pada tenaga pembangunan nasional yaitu, produk pendidikan yang tepat agar mampu menghasilkan sumber daya manusia Indonesia yang berkualitas dan memiliki daya saing yang tinggi.

Pendidikan nonformal sebagai sumber pembelajaran kepada masyarakat harus dapat dilihat sebagai daya dukung terhadap realisasi dan pengelolaan program, dan dijadikan sebagai pengembangan program di masa yang akan datang. Sedangkan peran masyarakat sebagai sasaran, dapat dilihat pada tingkat partisipasi masyarakat dalam mengikuti berbagai program yang berhubungan dengan peningkatan keterampilan, kemampuan, dan kualitas dirinya sehingga mampu meningktakan kesejahteraan sosial masyarakat miskin di daerah tersebut.

A developing country must use nonformal education not only to build upon the previous formal education of a small fraction of its citizens, but more especially to raise economic and social level of the vast majority of its citizens whonever acquired literacy, (Coombs, dalam Hoppes, 2006, p.39).

Dengan merujuk pada apa yang di sampaikan oleh Coombs di atas bahwa negara memiliki tugas dan tanggung jawab yang besar dalam mendorong kemajuan pendidikan nonformal untuk membantu masyarakat yang hidup dalam serba kekurangan. Mengingat bahwa konsep pendidikan nonformal merupakan bagian yang terpenting dalam sistem pendidikan dan memiliki tugas dan tanggung jawab dengan pendidikan yang lainnya. Maka sasaran sistem pendidikan nonformal yang semakin luas bukan hanya sekedar berhubungan dengan masyarakat miskin dan bodoh, tetapi sasaran pendidikan nonformal telah berkembang jauh sesuai dengan perkembangan ilmu pengetahuan dan teknologi yang begitu ketat persaingannya.

Dengan pendidikan nonformal sebagai salah satu pendekatan dalam pembangunan, maka manusia akan menjadi maju, berkualitas, dihargai di mata sosial, dan memiliki daya saing tinggi, dan pada akhirnya akan dapat meningkatkan derajat hidup sosial masyarakat dan dapat meningkatkan produktivitas kerja secara personal 
maupun secara nasional demi kemajuan bangsa dan negara. Saat ini kehadiran lembaga-lembaga sebagai salah satu jalur pendidikan nonformal di Kabupaten Halmahera Barat, patut dilakukan evaluasi secara menyeluruh kembali terkait dengan, peran, fungsi, dan kefokusannya dalam melaksanakan program-program untuk proses pemberdayaan. Selama ini lembaga-lembaga pendidikan nonformal yang berada di Dinas Pendidikan maupun di Dinas Sosial tidak berjalan secara baik dalam melakukan pengentasan kemiskinan. Padahal kita ketahui bersama bahwa peran lembaga-lembaga tersebut sangat besar dalam melaksanakan proses pemberdayaan kepada masyarakat miskin.

Konsep pendidikan nonformal merupakan konsep pendidikan dan pembelajaran yang berbasis pada masyarakat dengan tujuan agar masyarakat yang tidak menikmati pendidikan pada lembaga pendidikan formal, bisa mendapatkan di lembaga pendidikan nonformal, dengan harapan bisa dapat merubah pola pikir masyarakat dan dapat meningkatkan kehidupannya. Sehingga dapat terbentuk kesadaran ingin berusaha dan berjuang untuk merubah hidupnya melalui proses pendidikan nonformal masyarakat dapat diberdayakan.

Tidak berbanding lurus antara konsep dan kenyataan, bahwa lembagalembaga pendidikan nonformal yang berada di Kabupaten Halmahera Barat berdasarkan data yang dikeluarkan oleh Dinas Pendidikan Kabupaten Halmahera Barat tahun 2010, bidang Pendidikan nonformal dari sepuluh (10) PKBM (Pusat Kegiatan Belajar Masyarakat) dan memiliki lembaga kursus dan pelatihan sebanyak dua puluh sembilan (29) yang tersebar di Kabupaten Halmahera Barat yang aktif dalam melaksanakan pelatihannya hanya terdapat empat (4) PKBM (Pusat Kegiatan Belajar Masyarakat). Hal ini ditambahkan dengan data organisasi sosial (Orsos) yang dikeluarkan oleh Dinas Sosial Kabupaten Halmahera Barat pada tahun 2012, organisasi sosial yang berjumlah sebanyak 4 (empat), tersebar di empat kecamatan dalam lingkungan Kabupaten Halmahera Barat yang aktif dan berkembang hanya 2 (dua) Organisasi Sosial, yang lainnya tidak berkembang dan bahkan tidak aktif lagi.

Menurut data statistik Pemerintah Kabupaten Halmahera Barat, total masyarakat Halmahera Barat yang masuk dalam kategori sangat miskin, miskin, dan hampir miskin adalah 13,09\%. Angka ini sangat tidak sesuai dengan kondisi Sumber Daya Alam (SDA) yang dimiliki oleh masyarakat di Kabupaten Halmahera Barat.

Proses pemberdayaan masyarakat miskin melalui pendidikan nonformal, sesungguhnya merupakan sebuah upaya untuk memungkinkan masyarakat dengan segala keberadaanya dapat memberdayakan. Dengan pusat aktivitas harus berada di tangan masyarakat dengan bertitik tolak dari masyarakat, dilaksanakan oleh masyarakat dan manfaatnya untuk pemberdayaan masyarakat atau dengan kata lain pendidikan yang berbasis pada masyarakat dengan tujuan untuk meningkatkan kesejahteraan sosialnya yang harus dijadikan langkah strategis dalam menyelesaikan persoalan kemiskinan.

Jadi "Proses" akan menunjukkan pada suatu tindakan nyata yang harus dilakukan secara bertahap untuk dapat mengubah kondisi masyarakat yang lemah, baik dari aspek knowledge, attitude, maupun practice menuju pada penguasaan pengetahuan, sikap-perilaku sadar dan kecakapan keterampilan yang baik agar masyarakat dapat berdayakan untuk meningkatkan taraf kehidupan mereka dari kehidupan yang sebelumnya.

Secara konseptual bahwa pemberdayaan atau pemberkuasaan (empowerment), berasal dari kata 'power' (kekuasaan atau keberdayaan). Karena pemberdayaan bersentuhan dengan konsep mengenai kekuasaan. Kekuasaan seringkali dikaitkan dengan kemampuan kita untuk membuat orang lain melakukan apa yang kita inginkan, terlepas dari keinginan dan minat mereka. "Pemberdayaan bertujuan untuk meningkatkan kekuasaan orang-orang yang lemah atau tidak beruntung" (Ife, 1995 dikutip Suharto, 2010, p.58).

Ada tiga trategi pemberdayaan yang harus direalisasikan kepada masyarakat untuk dapat di berdayakan diantaranya, 
pemberdayaan secara politis, sosial, dan ekonomi yang diharapkan dapat mengatasi dan membantu atau paling tidak meminimalisir dampak-dampak negatif dari agenda neoliberalisme sehingga upaya untuk mewujudkan pembangunan yang berkelanjutan dan pembangunan yang berorentasi pada masyarakat dapat terwujud, (Suparjan dan Hempri: 2007, p.186).

\section{Starategi Pemberdayaan Politik}

Strategi ini bertujuan untuk diarahkan pada upaya membangkitkan kesadaran kritis masyarakat, sehingga mereka lebih tanggap terhadap persoalan ataupun kebijakan yang sebenarnya yang dapat merugikan mereka. Persoalan ini pemerintah perlu membuka ruang arena publik yang bebas, dimana individu dapat mengekpresikan aspirasinya secara bebas dan otonom, apalagi saat ini adalah jaman otonomisasi, pemerintah daerah memiliki kewenangan yang besar terhadap perlindungan hak dan kepentingan masyarakat.

Berkaitan dengan relasi masyarakat dan Negara pemberdayaan dapat diarahkan agar masyarakat memiliki kapasitas kontrol terhadap kebijakan Negara serta ikut dalam menentukan kebijakan dalam pmerintahan dan pembangunan. Agar ketika berhadapan dengan pasar, masyarakat diharapkan memunyai akses terbuka terhadap pasar yang sehat serta persaingan yang kompetitif demi kepentingan masyarakat.

\section{Strategi Pemberdayaan Ekonomi}

Selama ini pemerintah Indonesia telah terjebak dalam sebuah paradigma, bahwa pertumbuhan ekonomi identik dengan pendapatan Nasional yang besar sehingga mengabaikan ekonomi kerakyatan. Hal ini sesuai dengan fakta empiris bahwa ekonomi kerakyatanlah yang mampu bertahan dalam penyelamatan ekonomi Nasional. Oleh karena itu tidak ada alasan lagi untuk tidak mengakui eksistensi dan peranan ekonomi rakyat dalam percaturan ekonomi nasional.

Ekonomi rakyat adalah ekonomi yang mandiri yang tidak memiliki ketergantungan dengan modal asing. Hal ini yang perlu untuk dilakukan perlawanan terhadap kekuatan ekonomi global adalah dengan meningkatkan daya saing ekonomi nasional, bukan melalui cara seperti yang di suarakan oleh pakar-pakar ekonomi konvensional neo klasik. Ada beberapa basis kekuatan sosial yang diperlukan dalam membangun produksi ekonomi rumah tangga yakni perlindungan terhadap ruang kehidupan, pemberian pengetahuan dan keterampilan, pendekatan informasi, pemanfaatan organisasi sosial dan jaringan sosial serta pemanfaatan sumber daya keuangan, Friedman, dalam Suparjan dan Hempri, 2007, pp.188-189).

\section{Strategi Pemberdayaan Sosial}

Pemberdayaan sosial ini terkait dengan bagaimana upaya yang dilakukan untuk memberikan perlindungan terhadap masyarakat terkait dengan masalah perdagangan bebas yang saat ini telah merambah keseluruh belahan Indonesia. Dalam konteks ini posisi pemerintah sangat penting untuk ikut melibatkan dirinya untuk menyelesaikan persoalan-persoalan yang tidak dapat diselesaikan oleh kalangan masyarakat kecil, sehingga dibutuhkan campur tangan dari pemerintah secara langsung. Dalam konteks pemberdayaan sosial tersebut, menjadi sangat urgen bagi pemerintah untuk mengakomodasi dan merespon kebutuhan-kebutuhan masyarakat, sehingga terwujud kesejahteraan masyarakat. Pengalaman pembangunan selama masa orde baru, sebenarnya dapat menjadikan pelajaran yang berharga bagi pemerintah saat ini, bahwa strategi pembagunan yang dilakukan pada masa orde baru hanya berorientasi pada bagaimana pertumbuhan ekonomi, dan mereka mengabaikan aspek sosial, mengesampingkan potensi-potensi lokal masyarakat dan lunturnya nilai-nilai gotong royong, dan solidaritas antara warga masyarakat, sehingga berakibat pada konflik sosial yang tidak bisa di selesaikan sehingga berakibat pada pergantian rejim.

Dengan demikian aspek pemberdayaan sosial ini tidak bisa dikesampingkan, karena itu hal ini sangat penting untuk cepatnya di laksanakan mengingat, saat ini modal sosial masyarakat sudah mulai tergeser dari kehidupan sosial bermasyarakat, 
ini akibat dari pertumbuhan ekonomi dan perkembangan jaman yang begitu cepat sehingga pola kehidupan masyarakat itu lebih mengarah pada pola kehidupan yang individualistik.

Pemberdayaan atau pembangunan di daerah seharusnya di upayakan menjadi skala proritas penting dalam pembangunan kita di masa sekarang ini dan maupun di masa yang akan datang, upaya demikian sekurang-kurang perlu memperhatikan tiga hal penting antara lain, (a) bentuk kontribusi riil di daerah yang diharapkan oleh pemerintah pusat dalam proses pembangunan dasar, (b) aspirasi masyarakat daerah itu sendiri terutama yang terefleksi pada prioritas program-program pembangunan daerah, dan (c) keterkaitan antardaerah dalam tata perekonomian dan politik lokal.

Pemberdayaan pada hakekatnya mencakup dua aspek yaitu, to give or authority dan to give ability to enable. Dalam pengertian pertama, pemberdayaan memiliki makna memberi kekuasaan, sedangkan dalam pengertian kedua, pemberdayaan diartikan sebagai upaya untuk memberi kemampuan atau keberdayaan, (Suparjan, dan Hempri, 2003, pp.42-43). Pemberdayaan juga merupakan kunci untuk meningkatkan kualitas kehidupan masyarakat hal ini sejalan dengan disampaikan oleh Narayan yaitu: Empowermen is kef for: (a) Quality of life and human dignity, (b) good governance, (c) Pro-poor growth dan, (d) Project effectiveness, (Narayan, 2002, p.8).

Ada beberapa tahap pemberdayaan di bawah ini yang dapat dijadikan langkah awal untuk melakukan proses pemberdayaan antara lain, (Sulistiyani, 2004, p.83). (1) Tahap penyadaran dan pembentukan perilaku, merupakan tahap persiapan dalam proses pemberdayaan masyarakat. Tahap ini lebih menekankan pada sentuhan penyadaran akan lebih membuka keinginan dan kesadaran mayarakat tentang kondisi kehidupan saat ini; (2) Tahap proses tranformasi pengetahuan dan kecakapan keterampilan dapat berlangsung baik, penuh dengan semangat dan berjalan efektif jika tahap pertama telah terkondisi dengan baik; (3) Tahap pengayaan atau peningkatan intelektualitas dan kecakapan keterampilan yang diperlukan, agar mereka dapat membentuk kemandirian.

Berdasarkan uraian di atas, maka konsep pemberdayaan sebenarnya tidak sekedar merupakan proses belajar yang menekankan pada oreintasi dari proses serta pelibatan masyarakat. Hasil yang diharapkan dari proses pemberdayaan melalui pendidikan nonformal ini adalah tumbuhnya kesadaran dan kompetensi serta tanggung jawab sosial dan kapasitas masyarakat untuk membangun masa depan kehidupan yang lebih baik. Melalui pengkajian pemberdayaan masyarakat miskin melalui pendidikan nonformla, sebagai upaya meningkatkan kesejahteraan sosial di Kabupaten Halmahera Barat dapat diperoleh hasil yang memuaskan dalam mendorong masyarakat miskin untuk bisa dan dapat beradaya selama mereka mengikuti kegiatan pelatihan dan pembelajaran yang selama ini dilaksanakan pada lembaga-lembaga pendidikan nonformal di PKBM Mario Laha, PKBM Merpati, Orsos Tunas Harapan, Orsos Melati dan LPM Sonyinga.

Pada umumnya pelatihan yang dilaksanakan pada lembaga pendidikan nonformal hanya jangka pendek dengan prosedur yang sistematis dan terorganisir dengan tujuan tertentu. Di dalam Undang-undang Sistem Pendidikan Nasional, kelembagaan pendidikan nonformal meliputi, Lembaga Kursus, Kelompok Belajar, Majelis Taklim, Pusat Kegiatan Belajar Masyarakat (PKBM) dan lembaga-lembaga lain yang sejenis.

Lembaga pelatihan pendidikan nonformal yang baik dan mendukung terselenggaranya suatu pendidikan amat dibutuhkan dan turut berpengaruh terhadap pencapaian tujuan yang diinginkan. Bahwa dalam merumuskan lembaga pendidikan khususnya pendidikan nonformal itu sangat memengaruhi keberhasilan dan ketercapaian tujuan pendidikan dalam melaksanakan pelatihan untuk masyarakat yang tidak sempat berproses pada pendidikan formal, sebab lembaga/institusi ini merupakan tempat terjadinya proses aktifitas pembelajaran dan pelatihan berlangsung. 


\section{METODE}

Penelitian ini dilaksanakan di Kabupaten Halmahera Barat pada lembaga pendidikan nonformal yang terdiri dari PKBM Mario Laha, PKBM Merpati, Orsos Melati, Orsos Tunas Harapan, dan LPM Sonyinga. Waktu penelitian mulai dari bulan September 2012 sampai dengan Februari 2013. Penelitian ini menggunakan metode kualitatif dengan pendekatan fenomenologi, dengan subjek penelitian terdiri dari penggelola lembaga, warga belajar dan tokoh Masyarakat. Pengumpulan data menggunakan wawancara, observasi dan dokumentasi. Analisis data secara kualitatif dengan tahaptahap proses reduksi data, penyajian data dan penarikan kesimpulan.

\section{HASIL PENELITIAN DAN PEMBAHASAN}

\section{Hasil Penelitian}

Hasil wawancara antara penggelola, warga belajar dan tokoh masyarakat dapat di peroleh data bahwa selama ini kegiatan proses pemberdayaan yang dilaksanakan belum sesuai dengan harapan dan keinginan masyarakat miskin yang selama ini mereka terlibat dalam proses tersebut. Hal ini bisa dapat dilihat dari proses yang selama ini dilakukan oleh para penggelola untuk membantu masyarakat miskin untuk diberdayakan.

Proses pemberdayaan yang selama ini dilakukan pada lembaga pendidikan nonformal yang terdiri dari PKBM Merpati, PKBM Mario Laha, Orsos Melati, Orsos Tunas Harapan, dan LPM Sonyinga di Kabupaten Halmahera Barat belum dapat membantu dan menjembatani masyarakat untuk keluar dari persoalan kemiskinan yang selama ini mereka alami. Dalam perencaan program pelatihan penggelola tidak melibatkan para tokoh masyarakat maupun para warga belajarnya.

Program pelatihan yang dilaksnakan oleh PKBM, Orsos, dan LPM memilki keunggulan tersendiri, program yang dilaksanakan oleh lembaga-lembaga pendidikan nonformal tersebut sebagai berikut: PKBM Mario Laha dengan program keunggulannya adalah program kursus komputer, dan jahit menjahit, PKBM Mario Laha, jenis program pertukangan dan peternakan, Orsos Melati, dengan program populis yaitu, Aksesos atau (asuransi kesejahteraan sosial) dan usaha foto kopy, Orsos Tunas Harapan, Aksesos, sedangkan pada LPM Sonyingan terdiri dari program, kursus komputer, kursus internet, kursus, menjahit dan kursus instalasi listrik. Dari program-program tersebut selama ini dilaksnakan belum menunjukan hasil dalam membantu masyarakat dalam meningkatkan pendapatan ekonomi, apalagi sampai pada taraf sejahtera.

Di sisi yang lain juga bahawa, selama ini kegiatan proses pemberdayan yang diselenggarakan tidak mendapatkan bantuan operasional dari pemerintah daerah. Dari kelima lembaga pendidikan nonformal tersebut yang mendapatkan bantuan dari pemerintah hanya lembaga pendidikan nonformal yang berada dibawah naugan Dinas sosial, yang terdiri dari Orsos Melati, dan Orsos Tunas Harapan, itupun hanya sekali saja. Sedangkan PKBM Mario Laha, PKBM Merpati dan LPM Sonyinga, selama ini kegiatan pemberdayaan belum mendapatkan bantuan dari pemerintah daerah maupun pemerintah pusat. Kondisi inilah yang membuat lembaga-lembaga pendidikan nonformal tersebut tidak maksimal dalam menjalankan kegiatan pelatihan dan pembelajaran kepada masyarakat miskin untuk diberdayakan.

Dari kelima lembaga pendidikan nonformal yang dijadikan sebagai sasaran dan fokus penelitian selama ini dalam proses pemberdayaan yang dilakukan belum menunjukan tanda-tanda untuk peningkatan kesejahteraan sosial masyarakat miskin yang ada di kabupaten Halmahera Barat. Sesungguhnya harapan dari warga belajar atau masyarakat miskin yang ikut dalam kegiatan tersebut sangat mengharapkan mereka bisa dapatkan sesuatu yang selama ini mereka tidak miliki. Agar dapat dalam meningkatkan ekonomi keluarga.

Membangun hubungan kerja sama adalah membangun keparcayaan berarti membangun budaya, membangun budaya bukan hanya sekedar membangun adat, tradisi, dan kebiasaan akan tetapi membangun budaya berarti membangun kemampuan, keterampilan dan membangun sikap, di 
mana apabila ketiga hal ini dijadikan dasar dalam membangun hubungan kerja sama, maka yakin dan percaya lembaga-lembaga penyelenggara pendidikan nonformal tersebut akan tetap eksis dan bisa bertahan dalam menjalan proses pemberdayaannya. Kondisi ini berbeda dengan yang terjadi di lembaga pendidikan nonformal yang ada di kabupaten Halmahera Barat. Hasil penelitian menunjukan bahwa selama ini lembagalembaga pendidikan nonformal sangat mengesampingkan hubungan kerja sama.

\section{Pembahasan}

Proses pemberdayaan masyarakat melalui pendidikan nonformal, sesungguhnya merupakan sebuah upaya yang harus memungkinkan masyarakat dengan segala keberadaanya dapat memberdayakan dirinya. Dengan berpusat pada aktivitas masyarakat itu sendiri dengan berlandaskan pada prinsip dari masyarakat, dilaksanakan oleh masyarakat untuk masyarakat atau dengan istilah lain adalah pendidikan yang berbasis pada masyarakat.

Oleh karena itu "proses" merupakan langkah awal untuk menentukan sebuah keberhasilan program yang dilaksanakan, apabila proses itu berjalan sesuai dengan tahapan yang sesungguhnya maka hasil dari proses itu pasti baik, dan sebaliknya juga apabila proses itu tidak sesuai maka hasilpun juga akan tidak maksimal bahkan tidak tercapai dengan baik sesuai dengan tujuan dari lembaga atau organisasi yang bersangkutan.

Pemberdayaan sangat identik dengan pendidikan dan ini merupakan hakekat dalam pendidikan itu sendiri, karena apa yang disebut dengan pendidikan termasuk pendidikan nonformal adalah usaha yang dilakukan untuk memberdayakan manusia, meningkatkan derajat manusia, dan mengembangkan potensi-potensi yang ada pada diri manusia agar dengan kemampuan yang mereka miliki dapat dikembangkan melalui sebuah pembelajaran maupun pelatihan dengan harapan mereka bisa berdaya.

Dalam kaitannya dengan hal ini, ada lima prinsip yang harus dijadikan landasan dan dasar yang patut diperhatikan oleh lem- baga penyelenggara program pelatihan melaui pendidikan nonformal di anatarnya ialah: (1) keperdulian terhadap masalah, kebutuhan dan potensi/sumberdaya masyarakat; (2) kepercayaan timbal balik dari pelayan program dan dari masyarakat pemilik program; (3) fasilitasi (pemerintah) dalam membantu kemudahan masyarakat dalam berbagai proses kegiatan; (4) adanya partisipatif, yaitu upaya melibatkan semua komponen lembaga atau individu terutama warga masyarakat dalam proses kegiatan dan (5) mengayomi peranan masyarakat dan hasil yang dicapai. (Hiryanto dalam Yunus 2004, p.3).

Apa yang di jelaskan oleh Hiryanto tersebut terkait dengan prinsip-prinsip pelaksanaan pelatihan, tidak berlaku di lembaga pendidikan nonformal di Kabupaten Halmahera Barat, khususnya pada PKBM Mario Laha, PKBM Merpati, Orsos Melati, Orsos Tunas Harapan, dan LPM Sonyinga. Kehadiran PKBM, Orsos dan LPM yang ada di kabupaten Halmahera Barat seharusnya dapat dijadikan sebagai sebuah kendaraan atau alat untuk membantu masyarakat melalui prinsip tersebut, sehingga masyarakat dengan mudah untuk memahami proses ini dengan baik.

Dalam posisi tersebut bahwa pemberdayaan masyarakat miskin melalui pendidikan nonformal adalah sebuah proses untuk mengangkat harkat dan martabat seseorang atau kelompok masyarakat untuk menjadi memiliki pengetahuan yang didapatkan melalui proses pada pendidikan nonformal yang ada pada lembaga-lembaga penyelenggara program pelatihan tersebut. Sehingga lewat pelatihan ini kita dapat mewujudkan masyarakat yang sejahtera untuk dapat mengubah kehidupan sehari-hari.

Di sisi yang lain, terjadi pada PKBM Merpati dan PKBM Mario Laha, sangat di sayangkan saat ini kedua PKBM tersebut tidak lagi melaksanakan kegiatan pembelajaran pelatihan kepada masyarakat miskin. Kegiatan pelatihan selama ini berjalan hanyalah satu tahun mulai dari tahun 2007 dan itupun tidak maksimal dalam melakukan pelatihanya karena mereka tidak mendapatkan bantuan operasional dari pemerintah atau Dinas terkait dalam mendorong 
untuk mensukseskan cita-cita luhur dari lembaga pendidikan nonformal tersebut.

Saat ini lembaga pendidikan nonformal yaitu Organsiasi Sosial (Orsos) Melati dan (Orsos) Tunas Harapan, dan Lembaga Permberdayaan Masyarakat (LPM) Sonyinga, sampai saat ini ketiga lembaga masih tetap aktif dalam melaksankan proses pemberdayaan kepada masyarakat miskin, walaupun masih terdapat berbagai macam kendala dalam melaksanakan kegiatan ini. Dalam pelaksanaan kegiatan pelatihan ada beberapa langkah-langka yang seharusnya dapat diperhatikan oleh penggelola lembaga pelatihan dalam melakukan pelatihan dan pembelajaran, seperti yang disampaikan oleh Kamil antar lain adalah: (a) kondisi warga belajar, kondisi sumber belajar (tutor, dan prasarana lainnya (c) daya dukung pemerintah, tokoh dan lembaga organisasi lainnya masyarakat, dan (e) kemampuan kerja sama dengan pihak lain dalam mengembangkan program, (Kamil, p.6o)

Dalam perencaan program pelatihan para penggelola dapat melibatkan para tokoh masyarakat, dan warga belajar, dengan tujuan agar program-program yang diselengarakan oleh PKBM, Orsos dan LPM, itu sesuai dengan kebutuhan, kondisi dan keinginan masyarakat setempat. Sehingga kehadiran program tersebut dapat membantu masyarakat dalam meningkatkan kecakapan hidup secara individu, dengan harapan agar pasca pelatihan yang mereka ikuti selama pelatihan dapat membantu mereka untuk meningkatkan kehidupannya. Tetapi kondisi ini sangat berbeda dengan apa yang terjadi pada lembaga pendidikan nonformal tersebut, selama lembaga-lembaga pendidikan nonformal yang terdiri dari PKBM Mario Laha, PKBM Merpati, Orsos Melati, Orsos Tunas Harapan, dan LPM Sonyinga tidak pernah melibatkan para tokoh masyarakat dan warga belajarnya dalam melakukan perencanaan program.

Dalam pelaksanaan pelatihan pola rekrutmen peserta pelatihan, itu dilakukan oleh para penggelola dan tutor atau pendamping, masyarakat yang terlibat dalam pelatihan dan pembelajaran dibebaskan dari semua adminitrasi yang berkaitan dengan pelatihan. Langkah Ini dilakukan karena memperhitungkan kondisi masyarakat yang ikut dalam pelatihan ini adalah kebanyakan masyarakat miskin dan masyarakat yang kategori tidak memiliki kecakapan hidup. Kualitas kehidupan dapat tercapai apabila prmbelajaran yang dilaksanakan dapat berlangsung secara demokratis.

Pembelajaran yang demokratis dapat berlangsung apabila di dalam masyarakat terdapat fasilitas-fasilitas belajar yang memngkinkan masyarakat dapat belajar sesuai dengan kebutuhan dan keinginannya. Tetapi hal ini berbeda dengan yang dialami oleh lembaga pendidikan nonformal yang ada di kabupaten Halmahera Barat, bahwa hampir semua lembaga-lembaga tersebut tidak memiliki fasilitas yang cukup sehingga kegiatan-kegiatan pemberdayaan itu tidak berjalan secara maksimal. Kita ketahui bahwa keberhasilan dari sebuah program pelatihan dan pembelajaran itu terletak pada fasilitas dari lembaga tersebut. Salah satu faktor inilah yang mengakibatkan lembagalembaga pendidikan nonformal yang berada di Kabupaten Halmahera Barat tidak berhasil dalam melaksanakan kegiatan proses pemberdayaan kepada masyarakat miskin.

Secara konsep pendikan nonformal lebih mempunyai makna sebagai salah satu jalur pendidikan yang dapat dipilih oleh sebagian masyarakat, selain jalur pendidikan formal. Pendidikan nonformal dengan sifat pembelajaran yang fleksibel, berorientasi pada kebutuhan pasar dan masyarakat bertumpu pada kecakapan hidup mempunyai kemampuan untuk menembus seluruh lapisan masyarakat. Ini sesuai dengan motto Pendidikan nonformal yaitu,"menjangkau yang belum terlayani".

Secara teoritik bahwa sesungguhnya lembaga-lembaga pendidikan nonformal seperti PKBM, Orsos maupun LPM, itu memiliki peran yang sangat startegis dalam rangka untuk membantu masyarakat yang tidak memiliki pendidikan maupun skillnya. Kondisi ini jauh berbeda dengan yang terjadi di Kabupaten Halmahera Barat.

Salah satu kendala yang dihadapi oleh masyarakat miskin dan masyarakat pengganguran dalam meningkatkan kesejahteraan hidup adalah, masalah modal usaha. Bahwa yang terlibat dalam kegiatan pe- 
latihan ini adalah masyarakat yang memiliki latar belakang ekonomi yang lemah. Sehinggga kecakapan hidup yang diperoleh dari pelatihan itu saat ini hanya sebatas pada pengalaman semata. Belum sampai pada tingkat meningkatkan kesejahteraan hidupnya.

Hal ini seperti yang dikemukan oleh Nurlay, bahwa kurangnya optimal keberhasilan satuan pendidikan nonformal dalam meningkatkan kualitas hidup masyarakat dipengaruhi oleh banyak faktor di mana faktor-faktor tersebut saling mempengaruhi. Sehingga penyelesainnya harus dikordinasikan secara menyeluruh terhadap faktorfaktor tersebut. Di antara faktor-faktor tersebut antara lain: (a) kurangnya kordinasi antar lembaga pemerintah, swasta, dan masyarakat dalam penyelenggaraan program Pendidikan nonformal, (b) terbatasnya tenaga pendidik atau sumber belajar yang profesional, (c) motivasi belajar peserta relatif rendah, (d) masih terbatasnya terjangkauan pelayanan pendidikan nonformal bagi masyarakat, (e) kurangnya antisipasi program-program pendidikan nonformal untuk masa yang akan datang, (f) kurang meratanya pengadaan fasilitas-fasilitas pendidikan nonformal, (g) kebijakan pendidikan yang ada sekarang ini hanya menitikberatkan pada pendidikan formal, dan (h) kurang efesiensinya dalam penggelolaan sumber-sumber yang tersedia untuk meningkatkan kualitas hidup masyarakat, (Nurlay, 2012, pp.64-66).

Sudah banyak penelitian yang menggambarkan tentang keberhasilan pendidikan nonformal dalam memberikan implikasi nyata kepada masyarakat dalam meningkatkan kesejahteraan hidupnya. Ketika warga masyarakat memilki kecakapan hidup, maka dapat bekerja di perusahanperusahan atau mereka langsung dapat membuka lapangan kerja atau usaha baru secara mandiri. Melalui kerja dan usaha itu, kesejahteraan mereka bisa tercapai, bahkan kondisi ekonomi dan sosial keluarga juga menjadi lebih baik dari sebelumnya. Ini semua bisa terjadi, jika pemerintah daerah harus ikut aktif dan terlibat bersama-sama dengan lembaga-lembaga PKBM, Orsos dan
LPM untuk memberdayakan masyarakatnya.

Oleh sebab itu, program pendidikan nonformal yang dirintis harus memiliki tujuan dan orientasi yang jelas, agar kehadirannya mampu meningkatan pengetahuan, keterampilan, profesionalitas, produktifitas, dan daya saing masyarakat dalam merebut peluang pasar dan peluang usaha, yang pada sasarannya harus mampu mengatasi permasalahan yang dihadapi oleh masyarakat berupa kemsikinan, dan pengangguran. Karena tantangan pelaksanaan program pendidikan nonformal ke depan semakin besar untuk dihadapi oleh masyarakat. Kondisi seperti ini yang seharusnya dipikirkan oleh penggelola, dan pemerintah yang memiliki tanggung jawab besar untuk menyejahterakan masyarakat miskin yang berada di kabupaten Halmahera Barat.

Agar ke depan pelaku pendidikan nonformal harus mampu merekontruksi paradigma kepada masyarakat mapun pemerintah daerah bahwa pendidikan nonformal itu bukanlah pendidikan yang tidak mampu menjanjikan masa depan masyarakat. Tetapi pendidikan nonformal adalah pendidikan yang mempu memberikan masa depan kepada masyarakat. Karena konsep dari pendidikan nonformal itu memiliki keistimewaan tersendiri dalam mencerdaskan dan memberdayakan masyarakat. Dan ini telah diatur di dalam Undang-undang No 20 tahun 2003 Tentang Sistem Pendidikan Nasional.

Secara garis besar, kita sangat membutuhkan jejaring kerja (networking) untuk menjadikan kehidupan atau organisasi kita lebih sukses dan dapat bersaing. Demikian pula dengan PKBM, Orsos, dan LPM, jika mau dikatakan professional dan maju membangun hubungan kerja sama dengan semua pihak yang ada di Kabupaten Halmahera Barat pada khususnya dan Provinsi Maluku Utara pada umumnya. Sehingga semua program yang dilaksanakan harus dapat terkoneksi dengan berbagai sumber dalam suatu jejaring kerja (networking). Agar program-program tersebut dapat menjadi aikon dalam membangun masa depan masyarakat. 
Dengan kata lain, menjalin hubungan kerja sama sosial dengan siapa pun menjadi bagian terpenting dalam segala aktivitas kehidupan, apalagi PKBM, Orsos dan LPM, sebagai lembaga yang hadir untuk dari rahim masyarakat ini sendiri dengan berpusat dan bersumber pada masyarakat. Kondis seperti ini tidak terjadi pada PKBM Mario Laha, PKBM Merpati, Orsos Melati, Orsos Tunas Harapan, dan Lembaga Pemberdayaan Masyarakat (LPM) Sonyinga, yang terjadi pada lembaga-lembaga pendidikan nonformal tersebut tidak seperti yang digambarkan di atas. Saat ini lembaga tersebut hanya mambangun hubungan kerja sama di tingkat lokal dan ini dilakukan hanya dengan pemerintah daerah. Itupun juga tidak efektif hubungan kerja samanya.

Membangun hubungan kerjasama tidak selamanya harus dengan pemerintah semata, tetapi harus juga dengan lembagalembaga swasta atau organsiasi lain yang berda di kabupaten Halmahera Barat. Yang terpenting adalah bahwa lembaga-lembaga tersebut memiliki visi dan misi yang dalam membangun dan memberdayakan masyarakat miskin. Karena lembaga-lembaga pendidikan nonformal tersebut hanya sebagai wadah untuk melatih dan mendidik masyarakat yang tidak memiliki skill atu kecakapan hidup.

Ada beberapa prinsip yang harus diperhatikan dan jadikan sebagai dasar PKBM, Orsos, dan LPM dalam membangun hubungan kerja sama. Sehingga para pengelola dapat memahami dengan jelas, bahwa membangun hubungan kerja sama itu sangat penting untuk kemajuan lembaga maupun organisasi dalam masyarakat, prinsip-prinsip itu antara lain sebagai berikut: (1) Harus memilki kesamaan visi-misi; hubungan kerjasama hendaknya dibangun atas dasar kesamaan visi dan misi dan tujuan organisasi. Kesamaan dalam visi dan misi menjadi motivasi dan perekat pola kemitraan. Lembaga lembaga yang membangun hubungan kerja sama dapat bersinergi untuk mencapai tujuan demi kepentingan bersama; (2) Membangun kepercayaan (trust), harus ada rasa saling percaya antar pihak yang bermitra. Karena kepercayaan adalah modal yang paling mendasar dalam membangun hubungan kerja sama jejaring; (3) Saling manguntungkan, tujuan agar kerja sama dapat menguntungkan merupakan fondasi yang kuat dalam membangun kemitraan; (4) Menjaga efisiensi dan efektivitas; dengan menjaga efisiensi tersebut tentu saja tidak mengurangi kualitas proses dan hasil. Justru sebaliknya dapat meningkatkan kualitas proses dan produk yang dicapai. Tingkat efektifitas pencapaian tujuan menjadi lebih tinggi jika proses kerja kita melibatkan secara bersama-sama.

Dengan demikian dengan adanya prinsip-prinsip tersebut di atas diharapkan agar PKBM, Orsos, dan LPM ke depan lebih memahi akan penting membangun hubungan kerja sama antar lembaga bukan sebatas dengan pemerintah daerah setempat saja, dengan lembaga apapun dengan memerhitungan dasar dan prinsip-prinsip tersebut diatas.

\section{SIMPULAN DAN SARAN}

\section{Simpulan}

Proses pemberdayaan masyarakat miskin melalui pendidikan nonformal yang dilaksankan pada PKBM Merpati, PKBM Mario Laha, Orsos Melati, Orsos Tunas Harapan dan Lembaga Pemberdayaan Masyarakat (LPM) Sonyinga, pada implementasinya tidak sesuai dengan konsep tujuan awal.

Dampak dari proses pemberdayaan kepada masyarakat miskin belum ada peningkatan pendapatan masyarakat apalagi sampai pada tingkat kesejahteraan hidupnya.

Hubungan kerja sama selama ini dibangun oleh lembaga pendidikan nonformal khususnya pada PKBM Mario Laha, PKBM Merpati, Orsos Tunas Harapan, Orsos Melati, dan LPM Sonyinga di Kabupaten Halmahera Barat belum maksimal.

\section{Saran}

Bagi penyelenggara pelatihan, perlu memperhatikan keseriusan dan komitmen dalam membangun dan mengembangkan PKBM, Orsos dan LPM, dalam rangka melaksanakan pemberdayaan kepada masyarakat miskin. 
Perlu adanya pendampingan yang harus dilakukan secara efektif dan berkesinambungan kepada lembaga pendidikan nonformal, sehingga PKBM, Orsos dan LPM, agar dapat tampil kreatif dan inovatif.

Kepada lembaga-lemabaga instansi pemerintah maupun swasta perlu membuka peluang kerja sama yang selebar-lebar kepada PKBM, Orsos, dan LPM untuk turut serta bersama-sama dalam membangun dan membantu untuk membebaskan masyarakat Kabupaten Halmahera Barat dari cengkraman kemiskinan dengan harapan untuk bisa membantu meningkatkan kesejahteraan hidupnya.

Bagi pemerintah, agar memerhatikan lembaga-lembaga penyelenggara program pelatihan yang dilaksanakan oleh PKBM, Organisasi Sosial dan LPM tidak pandang sebelah mata.

\section{DAFTAR PUSTAKA}

Kamil, Mustofa. (2009). Pendikan nonformal (pengembangan melalui pusat kegiatan belajar mengajar PKBM di indonesia, sebuah pembelajaran dari kominkan japan). Bandung: Alfabeta
Sulistiyani. (2004). Kemitraan dan modelmodel pemberdayaan. Yogyakarta: Gaya Media

Sudarwati, Ninik. (2009). Kebijakan pengentasan kemiskinan (mengurangi kegagalan penanggulangan kemiskinan, Intimedia

Hoppes. W. (2006). Non-formal education and basic education refor: a conceptual review, International Institute For Education Planning

Sumarto. (2010). Jurus mabuk membangun ekonomi rakyat, Jakarta: Indeks

http://www.bps.go.id/ Data kemiskinan Indonesia pada bulan Maret 2012

Badan Pusat Statistik (BPS) Kabupaten Halmahera Barat, (2012)

Suparjan, Hempri. (2003). Pengembangan masyarakat, (dari pembangunan sampai pemberdayaan). Yogyakarta: Aditya Media

Narayan. (2002). Empowerment and poverty reduction. Washington DC: The World Bank 